\title{
Uranium in South Africa: Exploration and Supply Capacity
}

\author{
A. O. Kenan* ${ }^{*}$ E. Chirenje \\ Council for Geoscience, South Africa
}

Copyright $(02016$ by authors, all rights reserved. Authors agree that this article remains permanently open access under the terms of the Creative Commons Attribution License 4.0 International License.

\begin{abstract}
The major uranium deposits types are quartz-pebble conglomerate of the Central Rand Group (Witwatersrand Supergroup) and the Dominion Group, sandstone of the Karoo Uranium Province, surficial deposits of the Namaqualand region, as well as coal of the Springbok Flats Basin. Recent exploration activities (both greenfields and near-mine) have increased the resource potentials of these deposits. South Africa's Council for Geoscience has conducted high resolution magnetic and radiometric surveys in the Namaqualand region. Witwatersrand Basin is the only deposit where uranium mining is active at present in South Africa. Total uranium production in 2015 was $448 \mathrm{t}$. However, with production expected to increase in the Witwatersrand Basin, production is expected to reach $700 \mathrm{t} \mathrm{U}$ by the end of 2018 . Furthermore, with uranium production envisaged to begin in the Karoo Uranium Province, uranium production may exceed $1000 \mathrm{t} U$ by the year 2020 .
\end{abstract}

Keywords Uranium, Witwatersrand Basin, Karoo Uranium Province, Springbok Flats Basin, Namaqualand

\section{Introduction}

There are four major uranium deposits in South Africa, which are the Witwatersrand Basin (quartz-pebble conglomerate-hosted deposit), the Karoo Uranium Province (sandstone-hosted deposit), the Springbok Flats Basin (coal -hosted deposit) and Namaqualand surficial deposit (Fig. 1). The Witwatersrand Basin is located in the central parts of South Africa, and extends into Gauteng, Mpumalanga, and North West and Free State provinces with an area of more than $30,000 \mathrm{~km}^{2}$. The Karoo Uranium Province is located in the south-western part of South Africa, while the Springbok Flats Basin is located in the northern part of South Africa. The surficial deposits of the Namaqualand region occur in the north-western part of South Africa.

Uranium has been produced in South Africa since 1952. The highest uranium production in the country was attained in the early 1980 s where uranium production exceeded 6,000 tonnes of uranium. Since then, uranium production has steadily declined and reached 448 tonnes of uranium in 2015. It is envisaged that uranium production will increase in the near future. The South African government approved the Integrated Resources Plan 2010-2030 that will enable the increase in nuclear energy capacity from the current 1.8 GWe to 9.6 GWe by the year 2030. The current nuclear energy capacity requires about 294 tonnes of uranium per annum, and the expected expansion will require a total of $1536 \mathrm{tU}$ per annum. The government remains committed to nuclear energy capacity expansion, even though there are delays in the expansion progress. In addition, the global nuclear energy capacity is envisaged to expand significantly due to countries like China, Russia and India committing to nuclear energy expansion. It is on this backdrop that it expected that uranium demand will increase in the future, and hence have a positive effect in the uranium prices which will bring the deposits currently being investigated into production.

The methods used for this study includes aggregation of data (uranium resources and production) from literature reviews, annual company's reports, and other relevant reports. Uranium resources for some deposits, such as the Sun project North and South in the Free State Goldfields (Witwatersrand Basin), were estimated using ordinary kriging for gold grades, and linear regression for uranium grades. The resource estimation was done using old drill holes obtained from the Council for Geoscience's databases. These uranium resources were then aggregated with other uranium resources obtained from literature reviews to get the country's total resources. The uranium production forecasts was based on future projections from each mine that produces uranium, as well as from the uranium deposits that are expected to produce uranium within the next five years.

\section{Uranium Deposits}

There are seven known uranium deposits in South Africa, which are: quartz-pebble conglomerate, sandstone, coal, 
surficial, intrusive, granite-related, and phosphorite deposits. However, the major uranium deposits, which contribute to the nation's resource inventory, are quartz-pebble conglomerate, sandstone, coal, and surficial deposits (Fig. $1)$.

The Witwatersrand Basin consists of the economically important Witwatersrand Supergroup and the Dominion Group. The Dominion Group is disconformably overlain by the Witwatersrand Supergroup, and consists of a basal sedimentary horizon which contains uranium-bearing quartz-pebble conglomerates.

The Witwatersrand Supergroup is stratigraphically divided into Central Rand Group and West Rand Group. Economically, the Central Rand Group is the most important in terms of both gold and uranium resources. The Witwatersrand Basin represents a fluvial fan, or a fan delta, composed of many cycles of sedimentation. Uranium mineralization occurs in, or adjacent to, bands of quartz-pebble conglomerate which are preferentially developed at, or near, the base of each cycle of sedimentation where it is frequently associated with carbon of biogenic origin (Cole 1998). Rich concentrations of gold, uraninite and other detrital heavy minerals are associated with kerogen, particularly on major scour surfaces. The kerogen is believed to be syngenetic and derived from prokaryotic microbial mats. The only primary uranium mineral is uraninite, which is found to be extremely well sorted. Other uranium minerals include coffinite, and minor amounts of authigenic brannerite (Cole 1998; McCarthy 2006; Rob and Rob 1998).

The Springbok Flats Basin is fault-bounded graben, and trends northeast-southwest for about $190 \mathrm{~km}$. According to Cole 1998, uranium is concentrated in coal and carbonaceous shale in the upper part of the 'Coal Zone' over a vertical interval of $1 \mathrm{~m}$, within which there is a $0.1 \mathrm{~m}$ thick enriched zone. The uranium is disseminated in the coal and carbonaceous shale, with uranium phases having grain sizes of less than 20 microns. It is suggested that the uranium carriers were coffinite, oyamalite, auerlite, and solid solutions between coffinite and xenotime. A high proportion of uranium is probably held in organo-metallic compounds. The uranium in the basin is thought to have originated from granites of the Bushveld Complex and surround and underlie much of the Springbok Flats basin. Highest concentrations of uranium occur in the vicinity of granitic palaeoridges and beneath coarse-grained, pebbly sandstones of the Late Triassic Molteno Formation, where it discordantly overlies the 'Coal Zone'. Since uranium is confined to the uppermost part of the 'Coal Zone', it probably formed epigenetically from oxidized ore fluids that migrated from both the granitic palaeoridges and adjacent hinterland, as well as from Molteno Formation sediments, which contained abundant granitic detritus (Cole 1998).

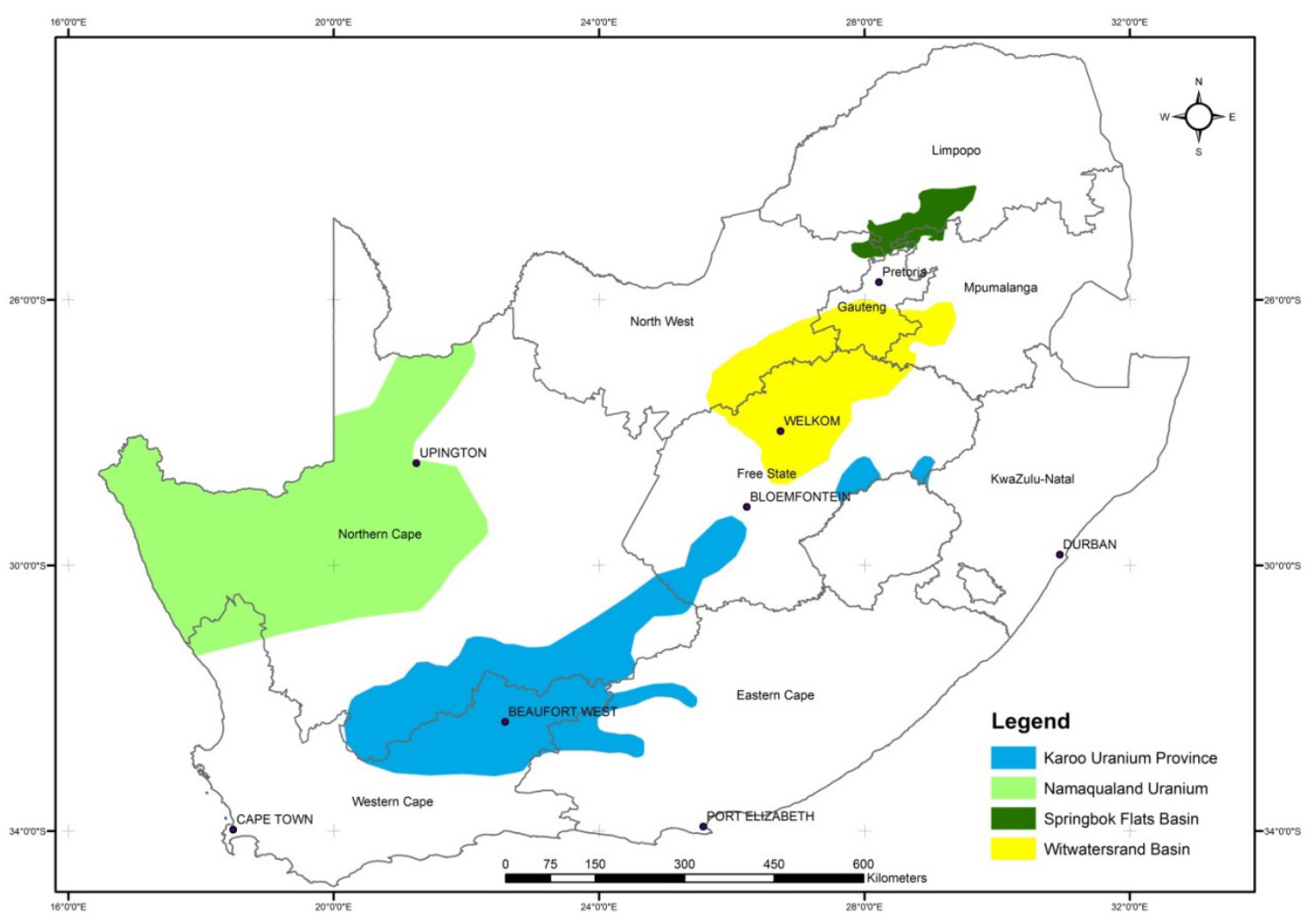

Figure 1. Map showing major uranium deposits in South Africa (Modified from Cole 1998). 
According to Cole and Wipplinger (2001), uranium in the main Karoo Basin (Karoo Uranium Province) occurs in the sandstones of the Beaufort Group (Upper Carboniferous to Jurassic) and specifically within the Adelaide Subgroup (lower Beaufort Group) in the south-western parts of the Karoo Basin. The Karoo Uranium Province includes a small satellite area located to the north of Lesotho, in central parts of South Africa. Adelaide Subgroup consists mainly of sandstone and mudstone, and to a minor extent mudstone-pebble conglomerate. The Beaufort Group sediments were deposited on a vast alluvial plain, in which abundant mudrock represents flood-plain and lacustrine deposits whilst the sandstone packages represent fluvial channel deposits. The majority of uranium-bearing sandstones are fine-grained in the main Karoo Uranium Province, and coarse-grained in the small satellite area in the north of the Karoo Uranium Province. Cole and Wipplinger proposed two types of sandstones that host uranium mineralization in the Karoo Uranium Province; these are laminated sandstone and carbonate-cemented sandstone. The uranium mineralization in the laminated sandstones occurs in the basal parts of the sandstone body and contains high values of both uranium and molybdenum. The uranium ore body in the laminated sandstones is generally tabular in shape. Uranium mineralization in the carbonate-cemented sandstones occurs at both the basal parts and elevated parts of the sandstone body, with uranium mineralization hosted by pods and lenses of fine-grained sandstone cemented by carbonate. In both the laminated sandstone and carbonate-cemented sandstone, uranium mineralization is restricted within areas that have presence of carbonaceous materials. The primary uranium minerals are coffinite and uraninite as well as secondary uranium minerals (uranophane, beta-uranophane, and carnotite) formed by recent oxidation (Cole and Wipplinger 2001).

According to Cole (1998), surficial deposits in the Namaqualand region can be subdivided into four types; lacustrine, fluvial, pedogenic and ferruginous mudrock. Currently, the most economically important surficial uranium deposit is the lacustrine type of the Henkries deposit. According to Hambleton-Jones (1986), lacustrine deposits in the Namaqualand region occur over pans in which the pans have either a purely internal drainage character with only an inlet, or are situated within drainages having both the inlets and outlets. Pan sediments in the Namaqualand region consists of salt, gypsiferous clay, massive gypsum, clay, sand and diatomaceous earth. The principal uranium mineral in these deposits is carnotite. However, other uranium minerals occur in minor amounts such as uraninite and urano-organic complexes. Fluvial deposits are located within sediments filling ancient valleys, with cementing material being dominated by calcite. Carnotite is the only identified uranium mineral in the fluvial deposit and is normally associated with calcrete or gypcrete cement (Carlisle 1980). The Tertiary to Recent surficial sediments of the Namaqualand region, filling palaeo-drainage channels, is mainly confined to the river courses with the main ones being the Koa and Sout. The valley-fill material was deposited under much lower gradients, especially on the Bushmanland Plateau, and the thicknesses are, consequently, of the order of only a few metres. Towards the Orange River, however, the sediments attain thicknesses in excess of $300 \mathrm{~m}$. In the Koa River valley the sediments tend to be upward-fining, having boulders and gravels near the base and well-sorted Aeolian sand higher in the sequence, some of which were probably reworked by fluvial action (Hambleton-Jones 1986). According to Hambleton-Jones (1986), the warping along the Griqualand-Transvaal axis has caused reduction in gradients, and in some areas, the gradients have been reduced to zero or even reversed causing ponding and the formation of pans. A typical example in this context of uranium distribution is Geelvloer. Cross-cutting dunes have formed, for example, at Dirkskop and Kamasoas in the Koa River valley. Humid climatic conditions, associated with increased Pleistocene glaciation, caused the formation of perennial lakes. Organic matter which accumulated in those lakes has been preserved as black organic-rich clays, peats, and diatomaceous deposits, for example the occurrences at Henkries and Kannikwa (Levin 1978).

\section{Exploration}

Exploration for uranium in the Witwatersrand Basin started in 1944. Currently, near-mine exploration in the Witwatersrand Basin is conducted primarily for gold, to increase the life of the operating mines within the basin. Drilling has been ongoing in the extensions of the Great Noligwa mining lease to determine the extent of remnant blocks of the Vaal Reef. Exploration targets have also been identified within the Kopanang mining lease and adjacent areas. On-going exploration and resource development work in the Cooke operations has highlighted numerous potential uranium resource extensions.

Uranium was discovered in the Karoo sandstones during oil exploration in 1967 by Southern Oil Exploration Corporation. Since 2005, more than $630,000 \mathrm{~m}$ of drilling has been completed and geophysically logged and additional $15,000 \mathrm{~m}$ of historic boreholes are available. The shallow nature of the mineralization and resources are potentially amenable to open pit mining. It has been proposed that alkaline leaching will be used for processing of ore, and production may start in 2018 (Peninsula Energy 2013).

Uranium was discovered in the Springbok Flats Basin in 1976 during exploration for coal in the basin. A pre-feasibility study was completed in 2012 in the Settlers area.

The surficial deposits in the Namaqualand region were discovered in 1975 as a result of airborne radiometric surveys. Exploration begun again in 2008, of which drilling was conducted and uranium re-evaluation was done with most of mineralization occurring within $20 \mathrm{~m}$ from the surface (Xtract Resources 2013). 


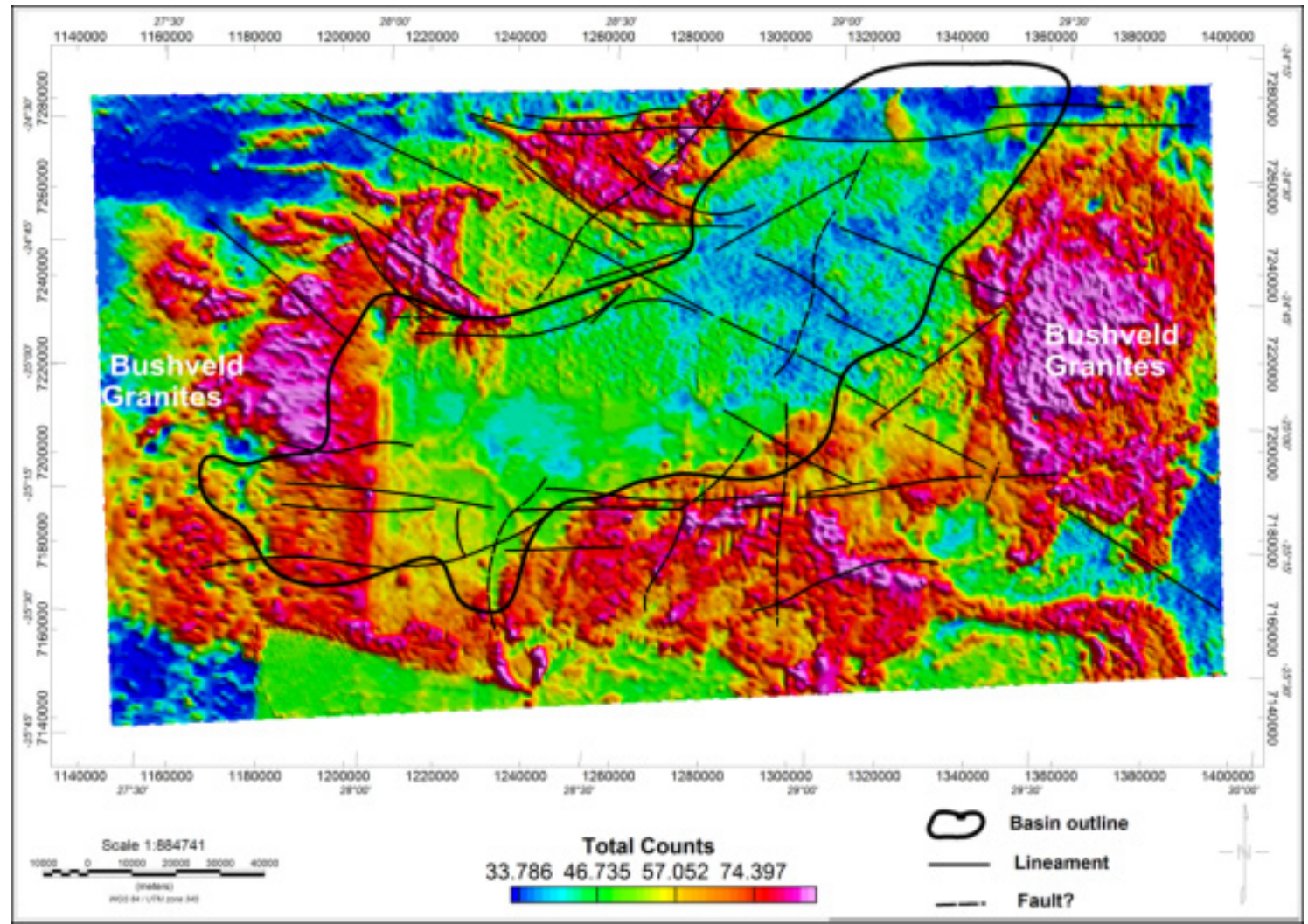

Figure 2. Regional radiometric map showing the locality of the Springbok Flats Basin and interpreted magnetics structures (CGS 2014).

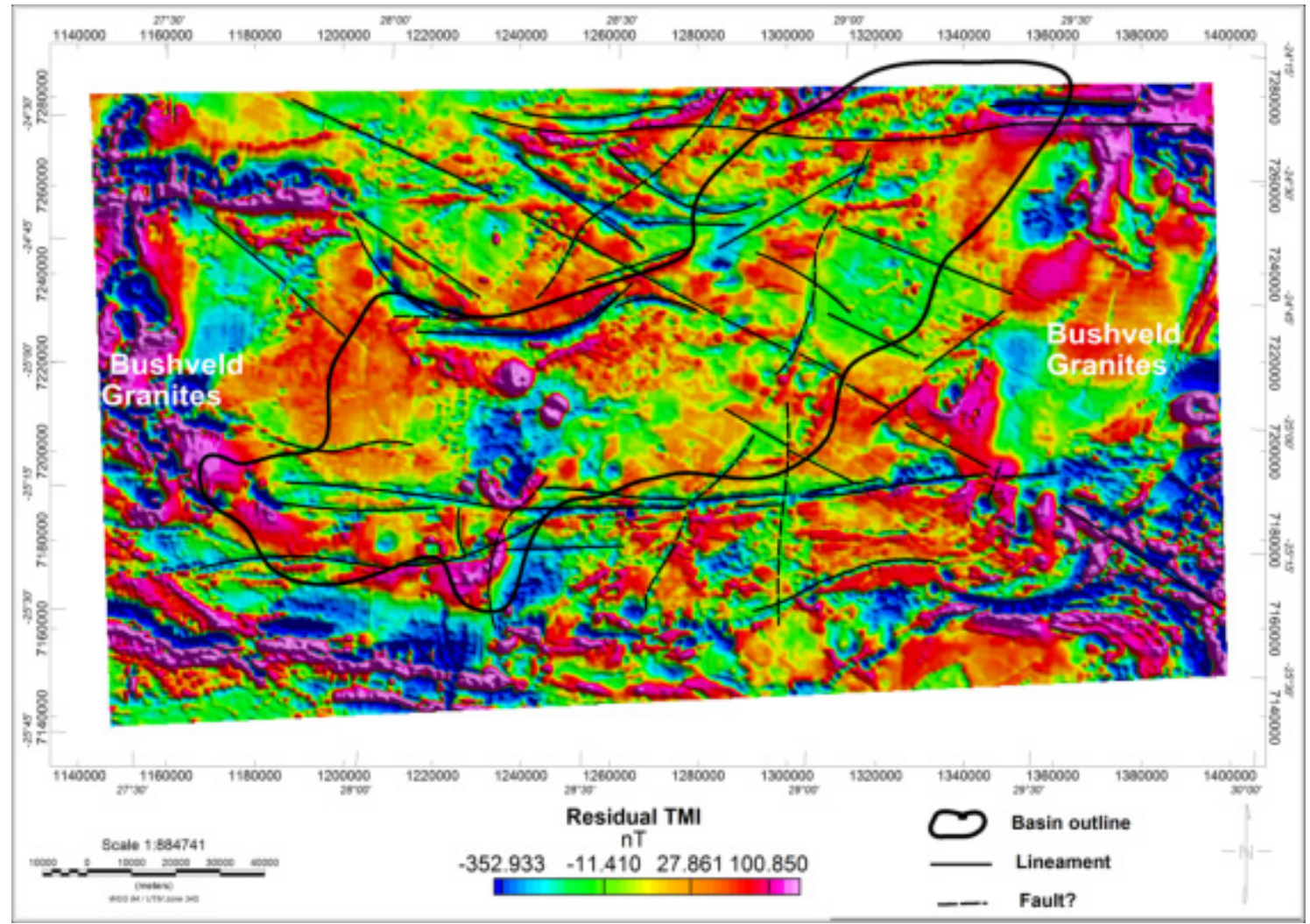

Figure 3. Regional magnetic map showing the locality of the Springbok Flats Basin and interpreted structures (CGS 2013). 


\section{Geophysical Exploration}

Regional geophysical data is available for the Springbok Flats (Figs 2 and 3). Uranium mineralization is too deep to be detected by airborne radiometric total counts but however the total counts image clearly show the outline of the basin owing to the contrasting Bushveld Lebowa Granite Suite surrounding the basin. The granites are believed to be the source of uranium in the coals and shales. The Department of Science and Technology of South Africa has provided funds to carry out downhole geophysics in the basin through partnership with exploration and mining industries that can offer access to boreholes data. Currently, there are on-going studies aimed at generating a three-dimensional geophysical model of the Springbok Flats Basin.

In Namaqualand, a high resolution airborne magnetic and radiometric survey was recently completed at $200 \mathrm{~m}$ line spacing and $80 \mathrm{~m}$ altitude over a selected block (Figs 4 and 5 ). These new data will be used for the generation of new mineral targets including uranium.

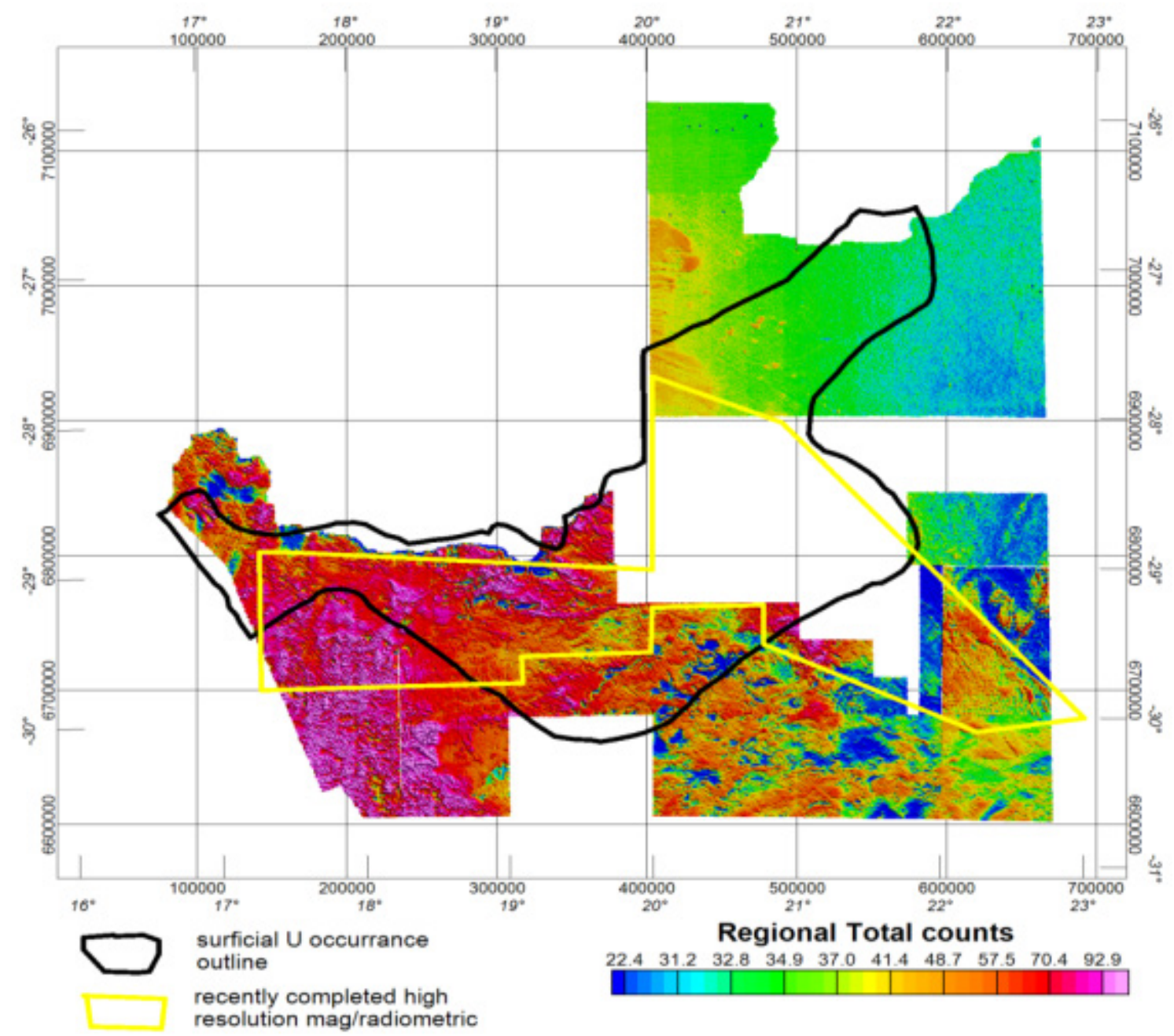

Figure 4. Illustration of the recently flown high resolution radiometric block (yellow) overlain on existing regional radiometric data map (CGS 2013). 


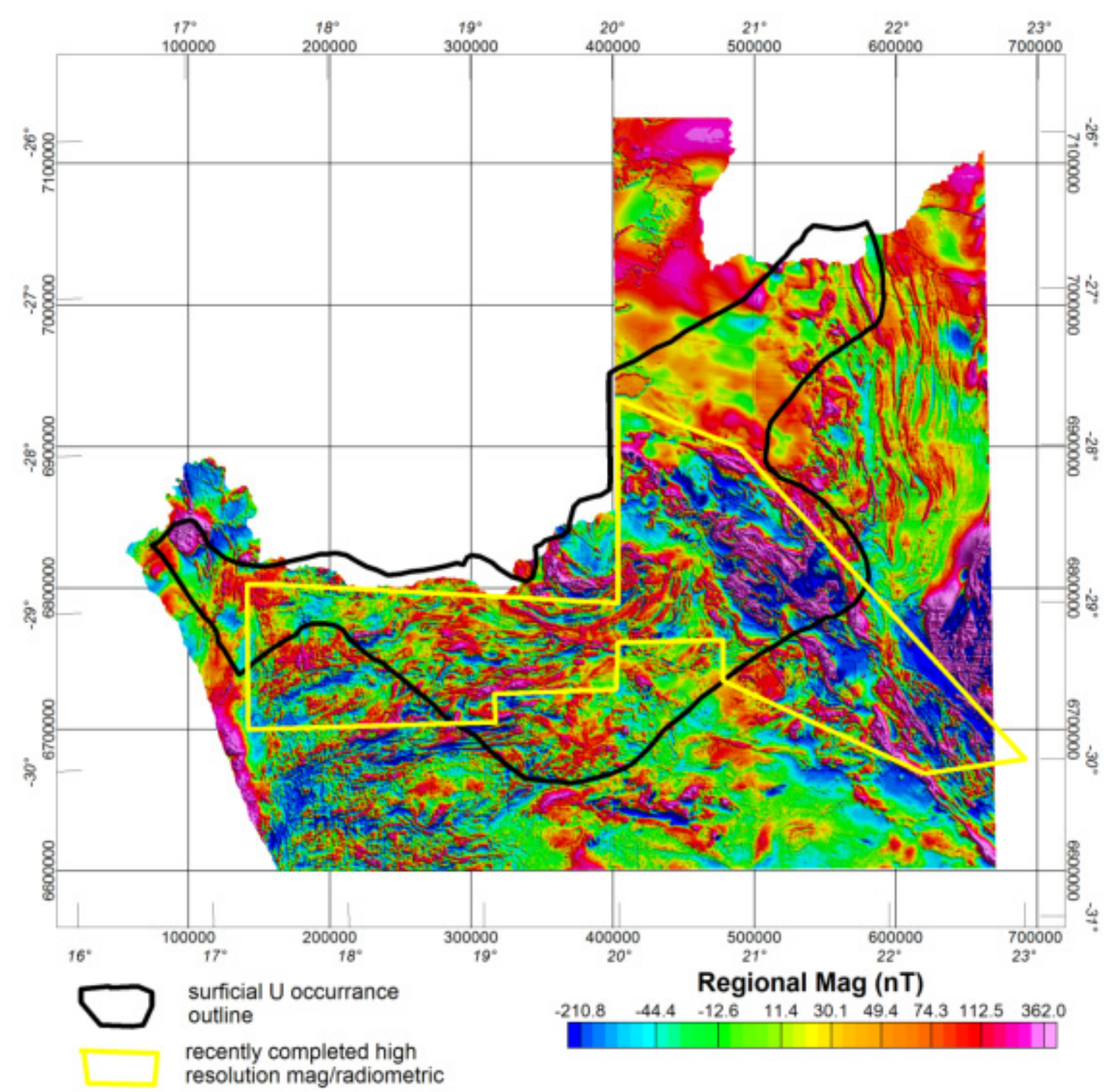

Figure 5. Illustration of the recently flown high resolution magnetics block (yellow) overlain on existing regional magnetic data map (CGS 2013).

\section{Resources}

The total contained in-situ uranium resources in South Africa is about $679,310 \mathrm{t} \mathrm{U}_{3} \mathrm{O}_{8}$ (which is equivalent to about 1820 million troy pounds (Mlb) $\mathrm{U}_{3} \mathrm{O}_{8}$ or $576,055 \mathrm{tU}$ ) as summarized in Table 1. The largest proportion of South Africa's identified in-situ uranium resources (about 84\%) are hosted by the quartz-pebble conglomerate of the Witwatersrand Basin and their associated tailings. About 12\% of the nation's in-situ resources are hosted by coal and carbonaceous shale of the Springbok Flats Basin, 4\% in the sandstones of the Karoo Uranium Province, and less than $1 \%$ in the Namaqualand surficial deposits (Fig. 6).

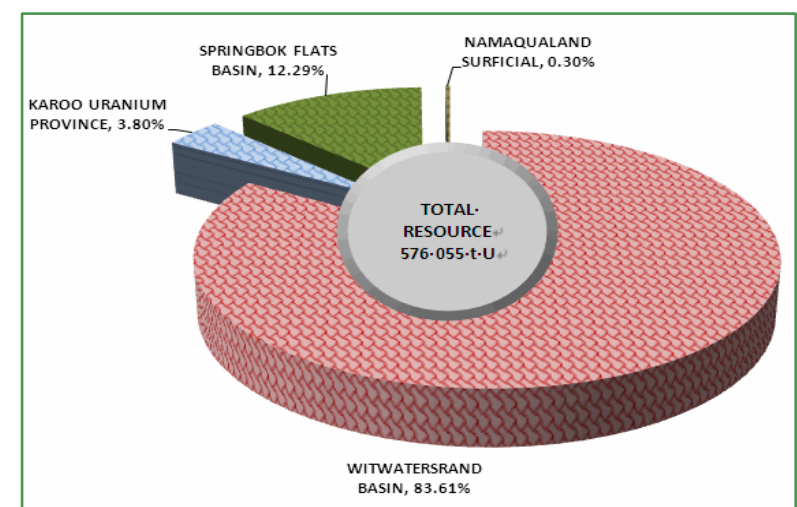

Figure 6. Proportions of South Africa's uranium resources in the major deposits 
Table 1. In-situ contained uranium resources in South Africa.

\begin{tabular}{|c|c|c|c|c|c|c|c|c|}
\hline \multirow[b]{2}{*}{ DEPOSIT } & \multicolumn{2}{|c|}{$\begin{array}{l}\text { MEASURED } \\
\text { RESOURCES }\end{array}$} & \multicolumn{2}{|c|}{ INDICATED RESOURCES } & \multicolumn{2}{|c|}{$\begin{array}{c}\text { INFERRED } \\
\text { RESOURCES }\end{array}$} & \multicolumn{2}{|c|}{$\begin{array}{l}\text { TOTAL RESOURCES } \\
\text { PER DEPOSIT }\end{array}$} \\
\hline & $\begin{array}{c}\text { metric } \\
\text { tonnes, } \\
\mathrm{U}_{3} \mathrm{O}_{8}\end{array}$ & $\begin{array}{l}\text { metric } \\
\text { tonnes, } \\
\mathrm{U}\end{array}$ & $\begin{array}{c}\text { metric } \\
\text { tonnes, } \mathrm{U}_{3} \mathrm{O}_{8}\end{array}$ & $\begin{array}{l}\text { metric } \\
\text { tonnes, } U\end{array}$ & $\begin{array}{c}\text { metric } \\
\text { tonnes, } \\
\mathrm{U}_{3} \mathrm{O}_{8}\end{array}$ & $\begin{array}{l}\text { metric } \\
\text { tonnes, } U\end{array}$ & $\begin{array}{c}\text { metric } \\
\text { tonnes, } \\
\mathrm{U}_{3} \mathrm{O}_{8}\end{array}$ & $\begin{array}{c}\text { metric } \\
\text { tonnes, } U\end{array}$ \\
\hline $\begin{array}{l}\text { WITWATERSRAND } \\
\text { BASIN (Palaeo-quartz } \\
\text { pebble conglomerate) }\end{array}$ & 47523 & 40300 & 219607 & 186227 & 300855 & 255125 & 567985 & 481651 \\
\hline $\begin{array}{c}\text { KAROO URANIUM } \\
\text { PROVINCE (Sandstone) }\end{array}$ & 0 & 0 & 9936 & 8426 & 15881 & 13467 & 25817 & 21893 \\
\hline $\begin{array}{c}\text { SPRINGBOK FLAT BASIN } \\
\text { (Carbonaceous shale and } \\
\text { coal) }\end{array}$ & 0 & 0 & 0 & 0 & 83462 & 70776 & 83462 & 70776 \\
\hline $\begin{array}{c}\text { NAMAQUALAND } \\
\text { SURFICIAL DEPOSIT } \\
\text { (Clay, diatomaceous earth, } \\
\text { calcrete) }\end{array}$ & 415 & 352 & 937 & 795 & 694 & 589 & 2046 & 1735 \\
\hline TOTAL RESOURCES & 47938 & 40651 & 230480 & 195447 & 400892 & 339956 & 679310 & 576055 \\
\hline
\end{tabular}

*Totals tonnages may differ from sum of the individual deposits' tonnages due to rounding.

\section{Production}

The majority of South Africa's uranium production (Fig. 7) has, historically, come from the Witwatersrand Basin as by-product of gold, with less significant uranium quantities coming from the Palabora carbonatite deposit as by-product of copper. Uranium production from Palabora carbonatite ceased in 2001.

Uranium in the Witwatersrand Basin is currently produced in the Vaal River (near the town of Orkney) and Cooke operations (near the town of Carletonville). In the Vaal River operations, the reef materials from Moab Khotsong, Great Noligwa and Kopanang are processed in the Noligwa gold plant/South Uranium plant circuit, while the ore from Vaal River tailings dams is processed at the Mine Waste Solution plant (AngloGold Ashanti 2013).

According to AngloGold Ashanti (2013), the Moab Khotsong and Great Noligwa mines were integrated into one mine in order to reduce high shaft costs as the Great Noligwa mine is aging and were designed in an era when cost pressures were significantly lower and grades were markedly better. The Great Noligwa ore body will now be accessed through Moab Khotsong, which will enhance efficiency. The primary reefs mined by these operations are the Vaal reef and the secondary Crystalkop reef. The reef is milled at the Noligwa gold plant and treated in the South Uranium Plant for uranium oxide extraction by the reverse leach process. Mining at Moab Khotsong is based on scattered mining method together with an integrated backfill support system that incorporates bracket pillars. Mining at the Kopanang mine is challenged by the presence of an assortment of steeply and gently dipping faults. The interplay of these faults, along with abundant pre- and post-dating dykes, makes for a complex and geologically challenging deposit. Currently, a study is underway to help improve the identification of the various geological homogeneous zones by incorporating alteration mineralogy. A sequential grid mining layout is used from which scattered mining takes place at Kopanang. The South Uranium plant throughput capacity is 263000 tonnes for a 30 day month, with an approximate uranium production capacity of $52 \mathrm{tU}$ per month. The ore materials from the Cooke operations are treated at Cooke 4 (Ezulwini) gold and uranium plants. Cooke 4 Uranium plant has a capacity of processing up to 100,000 tonnes of ore per month. A conventional acid leaching, ion exchange, solvent extraction and ammonium diuranate (ADU or "yellow cake") precipitation process is followed. The ore is treated in the uranium plant before being passed to the gold plant. This so-called "reverse leaching" process enables better gold recoveries. The ammonium diuranate slurry is shipped to Nuclear Fuels Corporation of South Africa (NUFCOR), located near Johannesburg, in tankers where it is calcined to uranium oxide $\left(\mathrm{U}_{3} \mathrm{O}_{8}\right)$ and sold to the conversion facilities overseas.

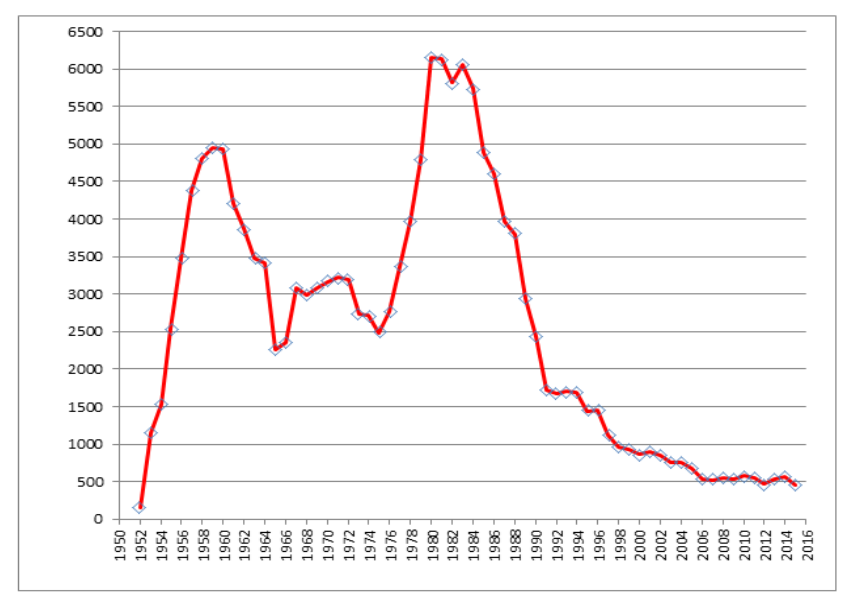

Figure 7. Graph showing historical production of uranium in South Africa (Precious Satsha 2016, pers. comm.).

The AngloGold's surface operations include the Mine Waste Solution which operates independently and processes slurry material reclaimed hydraulically from the various tailings storage facilities. The tailings are reclaimed using a 
number of hydraulic (high-pressure water) monitoring guns to deliver water at pressure. The tailings material is reclaimed by blasting the tailings storage facility face with the high-pressure water resulting in the slurry gravitating towards pumping stations. These monitoring guns can be monitored to selectively reclaim required areas from the tailing storage facilities. The reclamation strategy is aimed at mining the higher-grade first. The pump stations are located at the lowest point of the dams to ensure that the slurry from the dams will gravitate towards the pump stations from where the slurry will be pumped to the processing plants. The Mine Waste Solutions (MWS) uranium plant was commissioned during the fourth quarter of 2014. MWS uranium plant extracts uranium from the MWS flotation plant's concentrate product and has a throughput capacity of 100800 tonnes for a 30 day month with an approximate uranium production capacity of $25 \mathrm{tU}$ per month. The process involved employs a conventional sulphuric acid leach, counter current thickener decantation, counter current ion exchange, solvent extraction and ammonium di-urinate precipitation (AngloGold Ashanti 2013).Uranium production from Sibanye owned Cooke operations begun in May 2014, which resulted in an inventory of about $69 \mathrm{tU}$ at the end of 2014, even though no uranium was sold during the year. Uranium production costs at Cooke operations averaged approximately $62 \mathrm{USD} / \mathrm{KgU}$. The Cooke shafts are mining multiple reefs with Cooke 1 and 3 utilizing a combination of trackless and conventional mining. Conventional narrow reef stopping is the principal mining method employed, while trackless bord and pillar mining with $6 \mathrm{~m}$ bords is applied in the wider reef areas. The mining methods for Cooke 4 shaft are drift and fill with ade-stress cut conventional underground breast mining as well as board and pillar mining. Uranium processing is done at Cooke 4 (Ezulwini) Uranium plant. During mining, the gold ores from the Upper Elsburg reef and the gold/uranium ores from the Middle Elsburg reef are kept separate. The gold ores (from Upper Elsburg reef) are sent straight to the gold plant, while the gold/uranium ores (from the Middle Elsburg reef) are sent to the uranium plant first. Uranium production from Cooke operations is forecast at approximately 96 tonnes of uranium per annum by the end of 2015, and 106 tonnes of uranium by 2017 (Sibanye Gold 2015).

In 2015 , uranium production decreased by $21 \%$ to $448 \mathrm{tU}$ compared to 2014, due to safety-related stoppages (Figure 7). Other uranium supply potentials in the Witwatersrand Basin include the Dominion Reef mine (currently stopped uranium production), mines in the Free State Goldfield, as well as tailings facilities scattered throughout the Witwatersrand Basin. In addition, the deposits in the Karoo Uranium Province, Springbok Flats Basin, and Namaqualand surficial deposits represent future potential uranium suppliers. Therefore, uranium production in South Africa is expected to increase in the future, if uranium price becomes favourable to producers.

\section{Environment}

There are various environmental risks associated with uranium mining in South Africa (i.e., uranium as by-product gold in the Witwatersrand Basin) such as the acid mine drainage (AMD). According to Ramontja et al. 2000, several environmental risks associated with the acid mine drainage in the Witwatersrand Basin have been identified including risk owing to flooding of mines and decant of the AMD to the environment. The flooding of mines causes contamination of shallow groundwater resources required for agricultural use and human consumption, geotechnical impacts such as the flooding of underground infrastructure in areas where water rises close to urban areas, as well as increased seismic activity which could have a moderate localized effect on property and infrastructure. The decant of AMD to the environment can cause serious ecological impacts, regional impacts on major river systems, and localized flooding in low-lying areas. For example, the potential for inter-mine flooding at the Vaal River operations remains at risk, compounded by the failure of neighbouring mines to contribute to pumping costs. By the end of 2014, AngloGold Ashanti was pumping water from underground operations that it does not own, and that have ceased working, to prevent flooding of its current mine workings (AngloGold Ashanti 2015).

A generic approach to the management of the environmental risks associated with the AMD was proposed by Ramontja et al. 2000, for implementation in the three priority areas; decant prevention and management, water ingress control (reduction of the rate of flooding and the eventual decant volume), and water quality management. Ramonta et al. 2000 recommended that water must be pumped from the priority areas (mostly affected areas) to maintain accepted water levels, the water that will pumped out must be treated before use or before discharge to river systems, steps must be implemented to reduce the ingress of water into the underground workings as far as is possible, as well as improved monitoring of mine water, groundwater, surface water, seismicity, subsidence and other geotechnical impacts of mine flooding and related targeted research is required. The flooded mine voids are not the only sources of AMD in the Witwatersrand Basin, other sources such as mine residues need to be monitored and appropriately remediated to reduce AMD impacts.

\section{Conclusions}

South Africa's uranium production is forecasted to rise to 700 tonnes per year by the end of 2018, due to expected increase in the production from the Witwatersrand Basin ramp up in production at the Cooke operations and also other mining companies seeking to re-mine the tailings which contain considerable amounts of low-grade uranium.

Karoo Uranium Province is expected to start production before the year 2020, which will increase South Africa's 
uranium output to over $1000 \mathrm{tU}$.

\section{Acknowledgements}

The authors gratefully acknowledge the following organisations and companies for providing data and information: the Council for Geoscience, the Department of Mineral Resources, AngloGold Ashanti Limited, Peninsula Energy Limited, Harmony Gold Limited, HolGoun Uranium and Power Limited, Gold One International Limited, Sibanye Gold Limited, and Witwatersrand Consolidated Gold Resources Limited.

\section{REFERENCES}

[1] AngloGold Ashanti, 2013. Annual Report 2013. Accessed 20/5/20114] Ramontja, T., Coetzee, H., Hobbs, P.J., Burgess, J.E., Thomas, http://www.anglogoldashanti.com/en/Media/Reports/Annual \%20Reports/AGA-IR13.pdf

[2] AngloGold Ashanti, 2014. Annual Report 2014. Accessed 2/6/2015 http://www.anglogoldashanti.com/en/Media/Reports/Annual \%20Reports/AGA-IR13.pdf

[3] Carlisle, D., 1980. Possible variations on the calcrete-gypcrete uranium model. U.S. Dept. Energy, GJBX-53 (80) Grand Junction, CO (1980).

[4] CGS., 2014. Council for Geoscience geophysics data archives. Accessed on the $2^{\text {nd }}$ May 2014 at the Council for Geoscience.

[5] Cole, D.I., 1998. Uranium: In: Wilson, M.G.C., and Anhaeusser, C.R. (Eds.). The Mineral Resources of South Africa. Sixth edition, Council for Geoscience, $642-658$ pp.

[6] Cole, D. I., and Wipplinger, P. E., 2001. Sedimentology and molybdenum potential of the Beaufort in the main Karoo Basin, South Africa. Memoir, Council for Geoscience, 80. Pg. $1-225$.

[7] Hambleton-Jones, B.B., Levin, M., and Wagener, G.F., 1986. Uraniferous surficial deposits in Southern Africa in Mineral Deposits of Southern Africa, II (C.R. Anhaeusser and S. Maske, eds): Geological Society of South Africa, Johannesburg, p. 2269-2287.

[8] Levin, M., 1978. Uranium occurrences in the Gordonia and Pelindaba, PER-37, 24pp.

[9] McCarthy, T. S., 2006. The Witwatersrand Supergroup. In: Johnson, M. R., Anhaeusser, C.R., and Thomas, R.J. (Eds.). The Geology of South Africa. Geological Society of South Africa, Johannesburg/Council for Geoscience, Pretoria, 155 $186 \mathrm{pp}$.

[10] Peninsula Energy, 2013. Annual Report 2013. Accessed on the 5th May 2014 at http://www.pel.net.au A., Keet, M., Yibas, B., van Tonder, D., Netili, F., Rust, U.A., Wade, P., MareeMine, J., 2010. Water Management in the Witwatersrand Gold Fields With Special Emphasis on Acid Mine Drainage. Accessed on the 10th July 2016 at https://www.dwa.gov.za/Documents/ACIDReport.p df

[12] Rob, L.J., Rob, V.M., 1998. Gold in the Witwatersrand Basin. In: Wilson, M. G. C., and Anhaeusser, C.R. (Eds.). The Mineral Resources of South Africa. Sixth edition, Council for Geoscience, 294 - 349 pp.

[13] Sibanye Gold., 2015. Annual Report 2015. Accessed on the 10 June 2016 athttps://www.sibanyegold.co.za/investors/financ ial-reporting/annual-reports/2015 20th January 2014 at http://www.xtractresources.com/presen tations.htm Kuruman Districts. Atomic Energy Board, South Africa,

[14] Xtract Resources., 2013. Investor Presentation. Cited on the 